Section Editor

Mitchell S.V. Elkind,

MD, MS

Wallace J. Brownlee, MBChB, FRACP

Richard Roxburgh, MBChB, PhD, FRACP

Correspondence to

Dr. Brownlee:

wj.brownlee@gmail.com
Mystery Case:

\section{Cutaneous lesions in KRIT1-associated cerebral cavernous malformations}

\section{Figure 1 Axial susceptibility-weighted image}

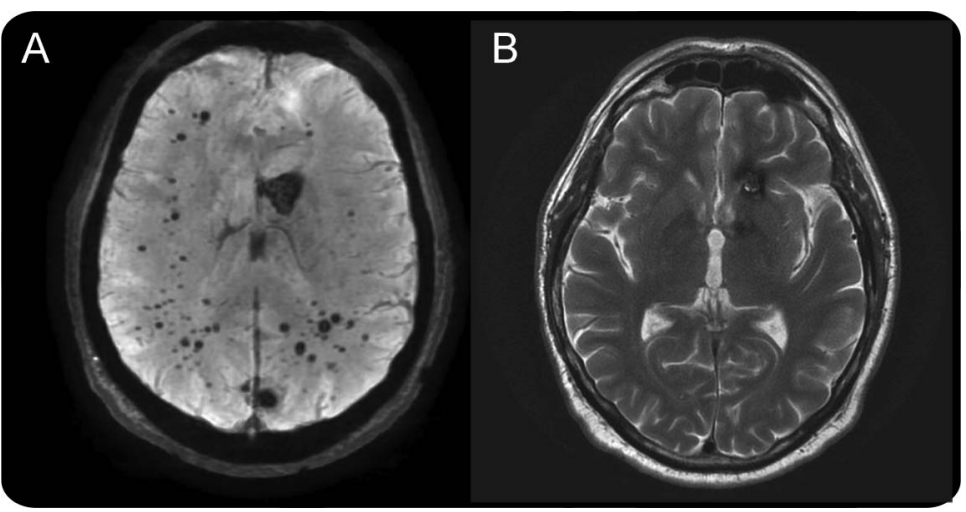

The image shows multiple areas of susceptibility in the cerebral hemispheres (A). Similar lesions were seen in the brainstem, cerebellum, and spinal cord. A number of the larger lesions had a typical popcorn appearance on T2-weighted imaging, characteristic of cerebral cavernous malformations (B).
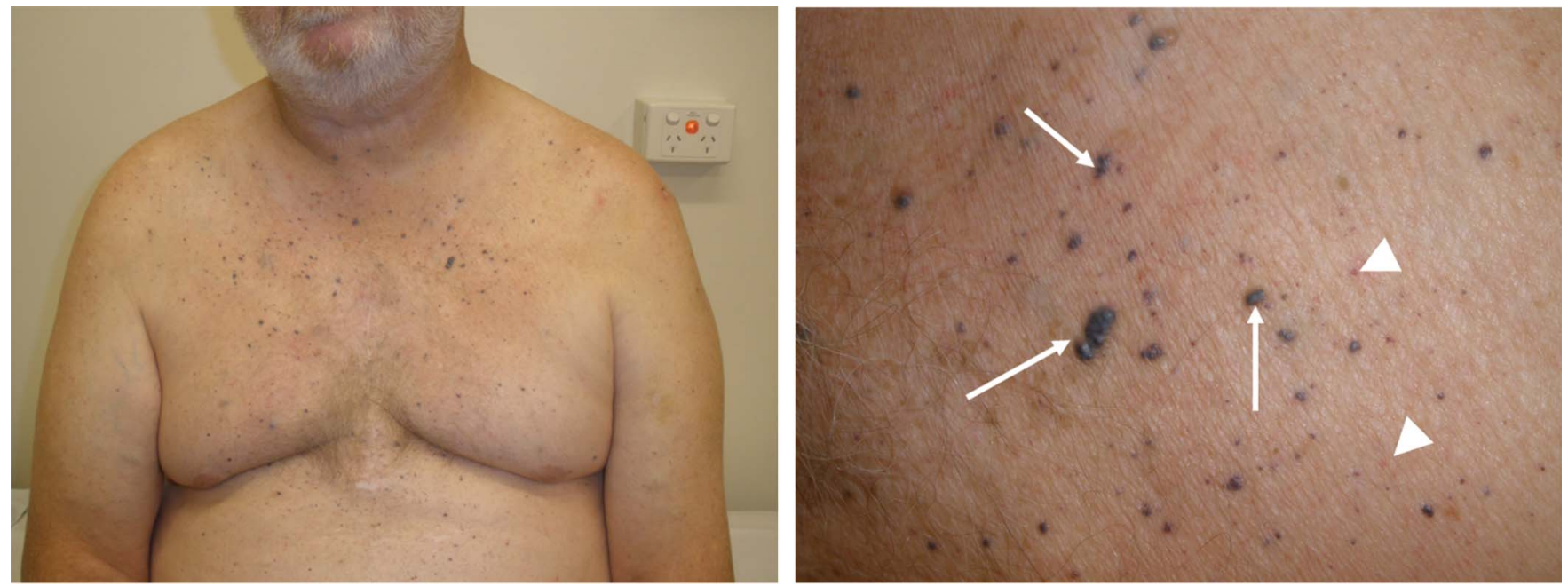

Nodular venous lesions (arrows) and red macules (arrowheads). Our patient did not display hyperkeratotic cutaneous capillary-venous malformations. These solitary, plaque-like lesions found on the limbs are present from birth.

An asymptomatic 65-year-old man was seen because of a family history of cerebral cavernous malformations (CCM) and a positive test for the KRIT1/ CCM1 (7q21.2) gene mutation. MRI of the brain showed multiple CCM (figure 1). The patient was noted to have innumerable skin lesions over the face, trunk, and limbs (figure 2). Cutaneous lesions occur in $9 \%$ of patients with familial CCM, particularly

From the Department of Neurology, Auckland District Health Board, New Zealand. 
with KRIT1 mutations. ${ }^{1}$ These include red macules, nodular venous malformations, and hyperkeratotic cutaneous capillary-venous malformations. ${ }^{1}$ Skin biopsy shows collections of abnormal, dilated thinwalled blood vessels. Familial CCM should be included with the neurocutaneous syndromes. ${ }^{2}$

\section{AUTHOR CONTRIBUTIONS}

Dr. Brownlee: preparation of the manuscript. Dr. Roxburgh: responsibility for the patient's clinical care, critical revision of the manuscript, and supervision.

\section{STUDY FUNDING}

No targeted funding reported.

\section{DISCLOSURE}

The authors report no disclosures relevant to the manuscript. Go to Neurology.org for full disclosures.

\section{REFERENCES}

1. Sirvente J, Enjolras O, Wassef M, et al. Frequency and phenotypes of cutaneous vascular malformations in a consecutive series of 417 patients with familial cerebral cavernous malformations. J Eur Acad Dermatol Venereol 2009; 23:1066-1072.

2. Kurlemann G. Neurocutaneous syndromes. Handb Clin Neurol 2012;111:513-533.

\section{MYSTERY CASE RESPONSES}

The Mystery Case series was initiated by the Neurology ${ }^{\circledR}$ Resident \& Fellow Section to develop the clinical reasoning skills of trainees. Residency programs, medical student preceptors, and individuals were invited to use this Mystery Case as an educational tool. Responses were solicited through a group e-mail sent to the American Academy of Neurology Consortium of Neurology Residents and Fellows and through social media.

All the responses we received came from individuals rather than groups. A total of $25 \%$ of respondents accurately identified the CCM demonstrated on MRI, and 13\% identified the patient's cutaneous capillary-venous malformations. The most complete response came from Violet M. Aroon, who correctly pointed out that familial CCM is the probable diagnosis and that a mutation in the KRIT1/CCM1 gene is the most likely underlying etiology.

This case highlights the value of obtaining a family history and performing a systemic examination to reach a rare diagnosis that might otherwise remain elusive.

Andrew Schepmyer, MD

University of British Columbia, Vancouver, Canada 


\section{Neurology}

\section{Mystery Case: Cutaneous lesions in KRIT1-associated cerebral cavernous malformations}

Wallace J. Brownlee and Richard Roxburgh

Neurology 2014;83;e133-e134

DOI 10.1212/WNL.0000000000000849

This information is current as of September 29, 2014

\section{Updated Information \&} Services

References

Subspecialty Collections

Permissions \& Licensing

Reprints including high resolution figures, can be found at: http://n.neurology.org/content/83/14/e133.full

This article cites 2 articles, 0 of which you can access for free at: http://n.neurology.org/content/83/14/e133.full\#ref-list-1

This article, along with others on similar topics, appears in the following collection(s):

Other cerebrovascular disease/ Stroke

http://n.neurology.org/cgi/collection/other_cerebrovascular_disease_s troke

Other neurocutaneous disorders

http://n.neurology.org/cgi/collection/other_neurocutaneous_disorders

Information about reproducing this article in parts (figures,tables) or in its entirety can be found online at:

http://www.neurology.org/about/about_the_journal\#permissions

Information about ordering reprints can be found online:

http://n.neurology.org/subscribers/advertise

Neurology ${ }^{\circledR}$ is the official journal of the American Academy of Neurology. Published continuously since 1951, it is now a weekly with 48 issues per year. Copyright () 2014 American Academy of Neurology. All rights reserved. Print ISSN: 0028-3878. Online ISSN: 1526-632X.

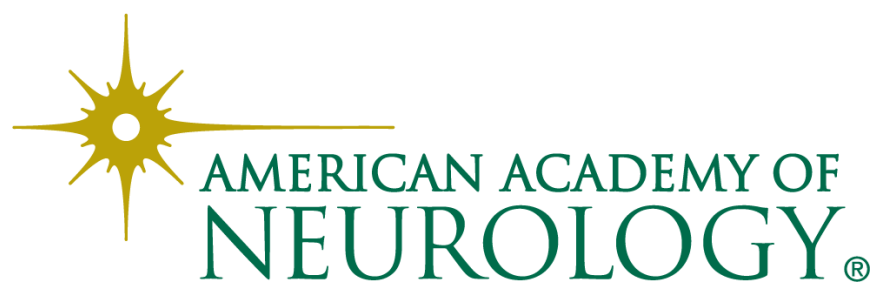

